\title{
THE ROLE AND PLACE OF SOCIAL PROGRAMMING IN PUBLIC GOVERNANCE
}

\author{
Venelin Terziev \\ Academician of the Russian Academy of Natural History, Moscow, Russia, Prof. \\ D.Sc.(Ec.), D.Sc. (National Security), D.Sc. (Social Activities), Ph.D., National Military University, \\ Veliko Tarnovo, Bulgaria; University of Rousse, Rousse, Bulgaria, terziev@skmat.com
}

\begin{abstract}
In its development, the concept of „programming” in its classic form is established in mathematics as a set of methods to create an algorithm of work of electronic computing machine ... a comprehensive computational process that aims at optimizing the mathematical expression in certain mathematical conditions. Applicable in its varieties of linear programming (method for finding the maximum or minimum of linear limiting function in the presence of linear restrictive conditions) and non-linear programming (set of mathematical methods for determining the largest and the smallest value of the non-linear functions in the presence of restrictive conditions), in the modern world of information technology this concept is key to the computer field (identified with coding). Moreover, in its broad interpretation, the term "programming" is associated with a range of actions in writing, which express prediction, foreshadowing, warning, statement, proclamation, prescription, command.
\end{abstract}

Keywords: social programming, social development, public governance, impact.

\section{INTRODUCTION}

The importance of social policy for the EU as a whole and for each member state individually, including Bulgaria, stems from the fact that social policy does not exist and develop independently and in isolation from other scopes of activity of the Union, but complements and unites all other EU policies. In this sense, it can be defined as a key policy for the overall development of the EU and the member states. Social problems already exist not only in the legislation field. We can point the Lisbon strategy as an example, which aims at economic, social and environmental renewal of the EU, as the economic development should not come at the expense of the social development, but the policy in terms of social development should contribute to economic development as well. In the early stages of development of the EU, social policy is seen as an extension and complement to the economic policy, as social and employment objectives are expected to be achieved automatically in the process of economic development. This leads, however, gradually to the realization that the economic integration is not an independent process, it has an important social aspect and it is more than necessary to combine the economic and social policy even to a greater extent. The enlargement of the EU and sharpening of social problems and unemployment in many member states bring the social policy and the idea that it is essential for the process of European integration to the fore. Economic and social policies complement each other and are aimed at building a society in which there is no isolation. It is hardly a coincidence that the motto of the EU, set forth in the new Treaty establishing a Constitution for Europe, is „United in diversity”, which emphasizes once again the importance of social policy 
for the development of European society. These are namely the reasons why we focus on social policy in its entirety and specifications. On the one hand, the development of this problem is directly related to the development of the processes in the EU and it is indicative of the degree of maturity of the Union and European society. On the other hand, the issues considered in the scientific work affect the interests of all of us. Social policy and employment are an area of great importance for Bulgaria. The complicated economic situation in the country during the transition period leads inevitably to severe social problems and tension. Along with solving the economic problems of the country, the solving of the social problems is of priority as well. A reason for this is the fact that only when there is social justice, security and peace for tomorrow in one society and the standard of living is high and stable, the public body functions properly and correctly. In this sense, one of the tasks is to show that in the process of EU accession Bulgaria managed to achieve the objectives of social policy and employment policy, which generally can be defined as: tackling social inequality and poverty, social exclusion and unemployment (Georgiev, 2016; Georgiev, 2017-a).

\section{THE ROLE AND PLACE OF SOCIAL PROGRAMMING IN PUBLIC GOVERNANCE}

In the modern socio-economic and political space, the phenomenon called social programming gained popularity. In order to clarify its nature and significance for the theory and practice of management in the public sector, we refer to the etymology of the concept of "programming", which roots come from Greek ("pro" - in advance, before and "Gramma"- write, mark). Hence its manifestation in the noun "program", which means „prescription”, „notice”, "work plan, action plan ... main tasks and objectives of the political party, public organization, public figure, etc. ... short presentation of the contents of a subject...".

In its development, the concept of „programming” in its classic form is established in mathematics as a set of methods to create an algorithm of work of electronic computing machine ... a comprehensive computational process that aims at optimizing the mathematical expression in certain mathematical conditions. Applicable in its varieties of linear programming (method for finding the maximum or minimum of linear limiting function in the presence of linear restrictive conditions) and non-linear programming (set of mathematical methods for determining the largest and the smallest value of the non-linear functions in the presence of restrictive conditions), in the modern world of information technology this concept is key to the computer field (identified with coding). Moreover, in its broad interpretation, the term "programming" is associated with a range of actions in writing, which express prediction, foreshadowing, warning, statement, proclamation, prescription, command.

In this range of meanings of the term "programming", the common thing is that it expresses a certain aspect of human activity, namely the preliminary planning of future actions and activities, with indication of their limitations. It is namely this aspect that is characterized by public nature, expressed in the need of decisionmaking on the one hand, and- of preparation of a program, expressing a certain prescription, public notice, on the other hand. In this sense, programming is the process of developing programs, as a particular model of purposeful activity for achieving a certain goal of public, economic and political development in the new world order.

According to the modern understanding of the concept of „programming”, it as a general principle of management on the basis of which the individual directs their actions by certain means to their purposes, in accordance with the dynamic changes of the surrounding environment. In other words, the specific content, structure and dynamics of the aim and the efforts for its achievement are affected by the challenges of the environment, in which the system works; by the extent of their understanding and dependence of the subject, its value orientation, priorities, the available opportunities and selected forms and methods for achieving the desired result. This determines more than ever the need for an alternative to the decisions and selection of the optimal variant, contributing to management by results. Based on this, the so-called program-targeted management approach arises. It is expressed in the „Planning-Programming-Budgeting-System” (PPBS).

Originated in the mid-60-s in the USA as a system for planning, programming and budgeting, the programtargeted management approach is first applied in the US Army. Based on the idea of accelerating the processes of revealing of the potential in a system with preliminary set objectives, the program-targeted approach enters quickly in the late 60 s and early 70 s in civic life (originally outside the material and later within the material sphere). That is why the PPBS is regarded as progress in budgeting and a management „miracle". In support of this are the words of the US President at that time, Johnson, who states: "This system shall ensure the implementation of the new tasks faster, better and cheaper; better decisions shall be generated through more and better information... Our decision-making process should have the same level as the one associated with armaments and defense. Briefly and clearly said, we need to replace our donkey carts with trucks and our old tools with new missiles".

What makes this approach unique for application is precisely the integration of its three main components- 
objectives, programs, program-targeted structure. And if the objectives are associated with the mission (the strategy) and hence the need for "unity of the objectives within an organization and provision of a basis for allocation of organizational resources", and therefore revealing of the organizational potential, then the programs appear to be the specification of the ways to use the resources for realization of the objectives. In order to do this, each program contains certain tasks distributed over time and referred to the respective executors. Therefore, each component of the PPBS expresses specific management phases. Thus, the planning determines the long-term objectives, specifying what is firmly intended to be done. Programming is associated with the analysis and evaluation of ways and possibilities for realization of the objectives (development and choice of alternative programs) in line with the "cost-effects (benefits)" analysis and the application of quantitative methods for management. In other words, the program is a plan with certain terms (dates), indicating the time when what is firmly intended to be done shall be done. Budgeting (funding) is associated with the selection of the most profitable and most effective programs and their inclusion in the budget for funding and implementation. And since the budget is nothing more but a program with specified prices, it gives an idea of how much funds are needed and when they should be provided to enable the implementation of what is firmly intended to be done at the right time.

Through the systematic approach, the specified management phases are integrated into a single system on an interconnected base and in a specific connection and dependence on funding. That is why one of the most respected experts in the field of program management - Charles Hitch (former president of the University of California and former Deputy Minister of Defense of the USA) determines the PPBS as a "program financing" based on the principles typical of the modern management practice. Of utmost principles are the principles for:

- Long-term objectives and expected outcomes;

- Prioritization and sequence of activities and classification of the resources in terms of their limitedness;

- Complexity in studying every problem- consideration of every issue or separate area of activity as a system. Hence, the consideration of each system as an integral part of such system of upper class and subjection of the objectives and tasks of the different subsystems to the common objective of the system;

- Multivariate character of the solutions, ways and means for reaching a certain objective, which requires the development of alternatives for action;

- Evaluation and comparison of the effectiveness of different alternatives based on objective criteria and with the help of the system analysis and its instruments (modeling, economic and mathematical methods of investigation and analysis of the value, cost-effectiveness or cost-utility, the method of operations research, mechanical and playing simulation, etc.);

- Continuity of planning or the implementation of the so-called continuous planning horizon and implementation of the necessary adjustments of the plans and programs in the process of their execution.

- Combining the program-targeted approach in the management with the funding of the programs in accordance with the degree of achieving the objectives.

Hence, the basis for functioning of the PPBS is the applying of the economic approach to each activity- the subject of management, the management based on the systematic approach and analysis, financing on a program-targeted basis, which by their nature are three fundamental theoretical and methodological positions. This is what determines the PPBS as a management concept with specific goals and tasks. More significant of them are:

- Outlining of the national goals;

- Coordination of the activities at the different levels with those goals;

- Analysis and valuation of the possible options for action;

- Increasing the role and effectiveness of control by funding.

- The coordination of the activities of the management system and its direction for the implementation of pre-defined objectives is namely the content of programming. The valuation of the possible alternatives and their analysis as well as increasing the role, importance and effectiveness of control is related to allocation of the resources, funding, which is actually the most important element of the system. On this basis, the positive characteristics of the PPBS are outlined, expressed in:

- The possibility to coordinate the planning and preparation for budgeting; 
- The applying of the method of continuous planning horizon on the basis of which the subordination and centralization of the process of decision-making is possible;

- The conducting of a long-standing analysis, which allows to weigh the pros and cons of each possible decision (global and rational), hence the choice of an appropriate for the objectives alternative;

- The economic soundness of the decisions made from the point of view of the usefulness and appropriateness of the costs;

- The connection of the implementation of the decisions made with their funding, which involves the simultaneous economization and effective use of the resources.

It is noteworthy that the PPBS presents the budget as a statement of general policy that defines the resources required for the implementation of the ultimate goals of management. At the same time, the system considers the activities as an intermediate stage of transforming of resources into services and usefulness of each program. And this is by its nature an expression of the "costs-effects" correlation, which is the basis of the management by results.

The PPBS has of course weaknesses as well. Given that some of the goals and objectives are specific, the opinion of the experts is that "the great difficulty and the main weakness of the overall system consists in the difficulty to formulate from the common and generally accepted culturally specific values such as peace, freedom, security, justice, education and healthcare such sub-goals that could serve as effective operating instruments of the current policy".

In its essence, the organizational system is such a system, the purpose of which is the coordination of the actions of purposeful parts, such as social groups and individuals, and direction (tools and means of action) with the overall goal to obtain a certain result (main end product).

In other words, programming in a certain form and way connects the purposeful part of the organizational system with the means and subjects of the activity. Thus, a hierarchy, distribution of powers, order and executive functions between the subjects of the program are created within the organizational system.

The strong correlation between the forms of the organizational system and the programming should be noted. The „hard" organizational system (conditionally called "administrative-command" system), as a rule determines the corresponding forms of programming and the types of programs from the type of the directive plan. The „soft” system (liberal-democratic system) only specifies the general reference points and recommendations for their achievement. In practice, however, we can also meet different symbiosis between "hard" and „soft" systems in diverse combinations of programming.

This is one side of the relationship between the forms of the organizational system and the programming. The other side is also worth mentioning. It involves the adverse impact of the form of programming and its products - the programs on the organizational system. The program that is created and fixed in a certain way can determine the particular form of the system. The program changes (corrections) as a rule lead also to corresponding changes in the system.

Programming is also directly related to another historically created approach for governmental impact. We talk about culture. Here, we can also find a deep relation, which is rooted in the essence of the culture. The culture is seen as "a specific way of human activity”, as a "collection of sustainable forms of activity". It is a basis for the life activity of the individual or the personal culture, the culture of the social group or the class culture, or the culture of society as a whole. This approach is complemented by axiological or value nature, the essence of which lies in the fact that culture is seen as „a set of human values”- all that exalts, ennobles and humanizes life and human relations (Terziev, Kanev, 2019; Terziev, 2019a-k; Terziev, 2018-d; Terziev, Georgiev, 2018e-f).

\section{THE SOCIAL PROGRAM AS A PRODUCT OF SOCIAL PROGRAMMING}

In its multi-aspect character, the word „program” enters broadly the sphere of public life and is also understood as a list, directory, communication (of theater, concert performances, performed roles and their performers, in radio and television programs, of authors of reports, scientific conferences and symposia), etc. The potential range of applicability of this concept is namely the basis of the transfer of its general meaning over even wider areas of applicability, within which to define its aspect meaning and content.

For the purposes of the study, determine the term „program” in the aspect of a public activity, such as the social one. In this sense, we use the term "social program" whose definition is reflected in several aspects.

It concerns the following: 
- The social program is a promising concept for welfare growth and development of social relations. It gives a general description of the strategy for social development of the country in a particular historical period, the main areas of well-being growth and global qualitative and quantitative indicators to be reached during this period. Such concepts are contained in the programming documents of the governing parties and serve as a basis for development of relevant sections of the plans for economic and social development;

- The social programs appear as special sections of the plans for economic and social development (annual or in the long run) of the relevant regions, districts and municipalities for planning. Reflecting the perspective social directions more thoroughly, they form the tasks for a certain stage and the ways for their achievement, reflect a deeper deployment of social criteria in planning, economic development as a whole and its individual sections. Moreover, they appear not only as a final result of the economy development planning, but as a combination of knowledge about it;

- The special social programs stand out, involving the solving of certain crucial social tasks and the corresponding concentration of resources. In this sense, the term "social program" is used mostly, although it refers to a narrower concept. Such programs often affect different sections of the socio-economic plans and require special coordination in the development of various sectors of the national economy.

The social programs contain specification of goals and objectives, reflect their hierarchy, serve for the formation of new forms to meet the social needs of the population and the formation of corresponding new organizational relations. As a social program, the combination of identified and feasible measures in a certain social field can reasonably be considered in case that no unified program document, plan, etc.is received, but are based on a common concept interlinked and aimed at reaching a comprehensive goal.

From the 70 s of the last century in the political and managerial vocabulary the term "target complex program" has been established, usually with the meaning of "directive and address document representing a combination of resources, contractors and deadlines for the implementation of a complex of interrelated tasks and activities, united by a common goal".

Recognizing the importance of such programs in the practice of management, it is necessary to note that their common name is not the most appropriate one. The adjectives "target" and "complex" characterize the attributive, immanent properties of each program and not only from the specific class. Non-target and noncomplex programs simply do not exist. Each program in an explicit or implicit form contains a target and a set or a complex of tools for implementation. This case once again confirms the importance of a terminology analysis and finding an adequate definition.

The term „program” started to be used by the American politicians and scientific communities to refer to a part of the budget process as a guideline for financial funds for the settlement of certain social and economic problems.

The equation of the term „program” with the term „plan” distorts the nature of the program-targeted approach to management and the integrity of the management phases- planning, programming, budgeting. Each of them performs specific functions in the management process and has certain products as a result. And if the planning phase is to answer the question "what” (shall be done), then the programming phase is to address the question "when" (shall be done), and the budgeting phase is to answer the question "how many" and „what" resources are needed (for what shall be done). What is important is that these are the questions of every management process, united by the question "Why". This is the reason why the differentiation of programming, as an intermediate phase between planning (setting of long-term goals) and budgeting (concretization of the connection of the objectives with the resources availability) should be sought. And that, more or less, expresses the "resources-skills-effects" correlation, which is the basis of the management by results.

Programming as the basis of management in the public sector, and in particular the management of resources of the state, is an intermediate stage between planning and budgeting in the implementation of the social policy of the state. The reason for social programming lies in the very nature of planning as a kind of prediction. The planning includes activities related to „allocation of resources, adjustment to external environment, internal coordination and organizational strategic cooperation". It is namely on the basis of the approach of continuous planning horizon that the future actions that are related to the social policy of the state are predicted and the balance between long-term priorities and short-term requirements and expectations of society for social policy of the state is provided. In other words, planning is directly related to programming. Moreover, the programs appear the connecting unit between mission, objectives and plans. They bind the targets with the resources, „reflecting the full potential for achieving the set goals” (material, financial, information resources). The results of the planning process are the programming instructions of various ministries and departments, which annually provide "criteria, objectives, priorities and medium-term 
financial framework, which are the basis for effective program management".

From the point of view of the social processes, the social programs can be defined as a structured dynamic image and a way of action (fixed within the program) for coordinated interaction between the bodies of power, directed to the solution of important social problems through resources, contractors and deadlines for the implementation of a set of tasks and measures.

Key element in the given description is the way of action and the associated with it certain method. Before performing any practical actions, the subject mentally builds their image "modus vivendi”. This complex thought process is based on the need and ability to meet a certain need that has an important role for the subject, in order to solve problems emerging as the ideal presumable result of the actions taken.

Within the current actions, the program answers the question „What should we do?”, but the answer to this question is inevitably linked with „How to do it“? By determining the way for the upcoming activity "modus operandi", the selection and order for use is composed of a combination of means for obtaining the desired result. These means may actually already exist or are to be created. In any case, they are pre-selected and arranged in a specific sequence and structure (logical and temporal). At this point, the structure and sequence of operations in the use of these means should be determined, respectively the efforts of the authors and executors of the program.

The multi-element and complex structure of the program, its temporality and the participation in it of a number of executors, determine the need for a documentary (significant) fixation and a tracking system of its implementation. In the process of implementation of both the individual components and the entire structure of the program, an activity may be reviewed, corrected, modified or terminated under the specified quality. Moreover, from this program for behavior and interaction between separate subjects, integrated programs could be drawn up that implement purposes, which have not been included in the intentions of the primary participants.

Last but not least, the term "program” is one of the most important characteristics of human activity, namely outpacing of any actions by their mental image. The program appears to be a special product of the individual and/or collective mental activity with practical and logical focus, and it appears as a generic category of very special or private structures in which to establish a specific model of a purposeful activity or concept of social development of the region, district or municipality, target programs for social protection of the population, a comprehensive employment program, etc.

Depending on the degree of decomposition of the priorities, the following levels of program development can be distinguished (Terziev, Arabska, 2014; Terziev, 2015-b; Terziev, Arabska, 2016a):

- At the first level major programs are developed, reflecting the objectives and tasks of social policies in line with the long-term development goals. Each major program includes: the program objectives, the organizational structures involved in the program, the responsibility for implementing the program, the external factors that could impact the achievement of program objectives, the necessary information sources and the three-year budget forecast on departmental and administered paragraphs of the program;

- At the second level the programs that identify the relevant components by type of social policies, are developed;

- At the third level the sub-programs are determined as a concretization of the programs in structures;

- At the fourth level, the program elements are defined that have relative autonomy, allow valuation, assessment and separate allocation of resources, reflecting on the social potential;

at the fifth level, the program sub-elements are differentiated, as details of the program elements by priority operations.

\section{CONCLUSION}

The practical implementation of the programs of each of the specified levels also includes some drawbacks. The development of the programs is often accompanied by conflicts of interest between the bodies of programming and budgeting. The lack of coordination between them, the lack of clear rules and procedures for determining the financial quotas by programs, can bring the objectivity and transparency of the financial commitment of the programs within the financial constraints in question. Moreover, it could make them unrealistic and threaten their feasibility due to lack of resources. This is the reason to search and understand the approaches to setting criteria and indicators for effective program activity and management impact of society through programming (Terziev, 2019). 


\section{REFERENCE LIST}

Georgiev, Marin. (2016). Obshtestvenoto i ikonomichesko razvitie v konteksta na sotsialnite politiki. // Spisanie za nauka "Novo znanie“. Visshe Uchilishte po Agrobiznes i Razvitie na Regionite, 5, 2016, N 4, str. 26-41, ISSN 2367-4598 (Online), (Print) ISSN 1314-5703 (Георгиев, Марин. Общественото и икономическо развитие в контекста на социалните политики. // Списание за наука „Ново знание“. Висше Училище по Агробизнес и Развитие на Регионите, 5, 2016, N 4, стр. 26-41, ISSN 2367-4598 (Online), (Print) ISSN 1314-5703.

Georgiev, Marin. (2017). Sbalansirovannaya karta kak alyternativa malogo biznesa. // Innovatsionnie tehnologii v nauke novogo vrmeni, Sbornik statey Mezhdunarodnoy nauchno - prakticheskoy konferentsii 1 fevralya 2017 g., Ufa NITS AETERNA, Chasty 1, 2017, s. 43-49, ISBN 978-5-00109004-5, ISBN 978-5-00109-007-6 (Георгиев, Марин. Сбалансированная карта как альтернатива малого бизнеса. // Инновационніе технологии в науке нового врмени, Сборник статей Международной научно - практической конференции 1 февраля 2017 г., Уфра НИЦ АЭТЕРНА, Часть 1, 2017, с. 43-49, ISBN 978-5-00109-004-5, ISBN 978-5-00109-007-6).

Georgiev, Marin. (2017a). Impacts of active social programs on labor market. // Mezhdunarodnayy nauchnayy zhurnal «Innovatsionnaya nauka». NITS Aeterna, N 02-1, 2017, pp. 139-143, ISSN 24106070 (Georgiev, Marin. Impacts of active social programs on labor market. // Международный научный журнал «Инновационная наука». НИЦ Аэтерна, N 02-1, 2017, pp. 139-143, ISSN 2410 6070).

Terziev, V., Kanev, D. (2019). Modern developments in behavioral economics. // Smart Technologies and Innovations in Design for Control of Technological Processes and Objects: Economy and Production Proceeding of the International Science and Technology Conference "FarEastCon-2018" Volume 138, October 2-4, 2018, Vladivostok, Russian Federation, pp. 10-23, 2019, (Print) ISBN978-3-030-15576-6, (Online) ISBN978-3-030-15577-3.

Terziev, Venelin. (2019a). Provision of integrated employment and social assistance services in Bulgaria. // Smart Technologies and Innovations in Design for Control of Technological Processes and Objects: Economy and Production Proceeding of the International Science and Technology Conference "FarEastCon-2018" Volume 138, October 2-4, 2018, Vladivostok, Russian Federation, pp. 24-39, 2019, (Print) ISBN978-3-030-15576-6, (Online) ISBN978-3-030-15577-3.

Terziev, Venelin. (2019b). Problems of control in the social sphere. // INTCESS 2019- 6th International Conference on Education and Social Sciences, 4-6 February, 2019, Dubai, International Organization Center of Academic Research, Istanbul, Turkey, pp. 577-593, ISBN: 978-605-82433-5-4.

Terziev, Venelin. (2019c). The criterion "competence" in the economic sector. // INTCESS 2019-6th International Conference on Education and Social Sciences, 4-6 February, 2019, Dubai, International Organization Center of Academic Research, Istanbul, Turkey, pp. 1241-1247, ISBN: 978-605-824335-4.

Terziev, Venelin. (2019d). Social policy and labor market development in Bulgarian transition period. // INTCESS 2019- 6th International Conference on Education and Social Sciences, 4-6 February, 2019, Dubai, International Organization Center of Academic Research, Istanbul, Turkey, pp. 703-714, ISBN: 978-605-82433-5-4.

Terziev, Venelin. (2019e). Theoretical basis of development of labor market and social policy in the republic of Bulgaria. // INTCESS 2019- 6th International Conference on Education and Social Sciences, 4-6 February, 2019, Dubai, International Organization Center of Academic Research, Istanbul, Turkey, pp. 715-726, ISBN: 978-605-82433-5-4.

Terziev, Venelin. (2019f). The problem of social efficiency- Indicators for social efficiency. // INTCESS 20196th International Conference on Education and Social Sciences, 4-6 February, 2019, Dubai, International Organization Center of Academic Research, Istanbul, Turkey, pp. 669-678, ISBN: 978605-82433-5-4.

Terziev, Venelin. (2019g). Experiencing social policy development and efficiency measurment. // INTCESS 2019- 6th International Conference on Education and Social Sciences, 4-6 February, 2019, Dubai, International Organization Center of Academic Research, Istanbul, Turkey, pp. 679-686, ISBN: 978605-82433-5-4.

Terziev, Venelin. (2019h). Efficiency and assessment of social technology. // INTCESS 2019-6th International Conference on Education and Social Sciences, 4-6 February, 2019, Dubai, International 
IJASOS- International E-Journal of Advances in Social Sciences, Vol. V, Issue 14, August 2019

Organization Center of Academic Research, Istanbul, Turkey, pp. 687-694, ISBN: 978-605-82433-5-4.

Terziev, Venelin. (2019i). Conceptual framework of social adaptation. // INTCESS 2019- 6th International Conference on Education and Social Sciences, 4-6 February, 2019, Dubai, International Organization Center of Academic Research, Istanbul, Turkey, pp. 494-503, ISBN: 978-605-82433-5-4.

Terziev, Venelin. (2019j). The dependence social adaptation- socialization. // INTCESS 2019- 6th International Conference on Education and Social Sciences, 4-6 February, 2019, Dubai, International Organization Center of Academic Research, Istanbul, Turkey, pp. 478-485, ISBN: 978-605-82433-5-4.

Terziev, Venelin. (2019k). Social activity and human resources as social development factors. // INTCESS 2019- 6th International Conference on Education and Social Sciences, 4-6 February, 2019, Dubai, International Organization Center of Academic Research, Istanbul, Turkey, pp. 546-553, ISBN: 978605-82433-5-4.

Terziev, Venelin. (2018). The active model of a social programme and its strategic advantage . // ADVED 2018- 4th International Conference on Advances in Education and Social Sciences Abstracts \& Proceedings, 15-17 October 2018- Istanbul, Turkey, International Organization Center of Academic Research, www.ocerints.org, Istanbul, Turkey, 2018, pp. 189-203, ISBN: 978-605-82433-4-7.

Terziev, Venelin. (2018a). Active social programs development in Bulgaria: contemporary challenges and social management instruments. // ADVED 2018- 4th International Conference on Advances in Education and Social Sciences Abstracts \& Proceedings, 15-17 October 2018- Istanbul, Turkey, International Organization Center of Academic Research, www.ocerints.org, Istanbul, Turkey, 2018, pp. 149-163, ISBN: 978-605-82433-4-7.

Terziev, Venelin. (2018b). Social assistance services and integrated employment in Bulgaria. // ADVED 2018- 4th International Conference on Advances in Education and Social Sciences Abstracts \& Proceedings, 15-17 October 2018- Istanbul, Turkey, International Organization Center of Academic Research, www.ocerints.org, Istanbul, Turkey, 2018, pp. 164-177, ISBN: 978-605-82433-4-7.

Terziev, Venelin. (2018c). Impact of the labor market policies for ensuring employment. // ADVED 2018-4th International Conference on Advances in Education and Social Sciences Abstracts \& Proceedings, 1517 October 2018- Istanbul, Turkey, International Organization Center of Academic Research, www.ocerints.org, Istanbul, Turkey, 2018, pp. 178-188, ISBN: 978-605-82433-4-7.

Terziev, Venelin. (2018d). Importance of human resources to social development. // ADVED 2018-4th International Conference on Advances in Education and Social Sciences Abstracts \& Proceedings, 1517 October 2018- Istanbul, Turkey, International Organization Center of Academic Research, www.ocerints.org, Istanbul, Turkey, 2018, pp. 204-212, ISBN: 978-605-82433-4-7.

Terziev, V., Georgiev, M. (2018e). A strategic framework for the development of social entrepreneurship in Bulgaria. // Knowledge - International Journal, August 2018, Institute of Knowledge Management, Skopje, Macedonia, 25, 2018, N 1, pp. 23-34, ISSN 1857-923X (for e-version), ISSN 2545 - 4439 (for printed version).

Terziev, V., Georgiev, M. (2018f). Support for the development of social entrepreneurship in Bulgaria. // Knowledge - International Journal, September, 2018, Institute of Knowledge Management, Skopje, Macedonia, 26, 2018, N1, pp.57-74, ISSN 1857-923X (for e-version), ISSN 2545 - 4439 (for printed version).

Terziev, V., E., Arabska. (2014). Assessment of active social policies' impacts on labor market in the Republic of Bulgaria. Kolektivnaya monografiya "Sotsialyno-ekonomicheskie i pravovay razvitiya ekonomiki“, Ufa, Aeterna. Rossiya, 2014. ISBN 978-5-906769-97-8, str. 3-57 (Terziev, V., E. Arabska. (2014). Assessment of active social policies' impacts on labor market in the Republic of Bulgaria. Колективная монография „Социально-экономические и правовы развития экономики“, Уфа, Аэтерна. Россия, 2014. ISBN 978-5-906769-97-8, стр. 3-57).

Terziev, Venelin. (2015). Impact of active social policies and programs in the period of active economic transformations in Bulgaria,„,East West”Association for Advanced Studies and Higher Education, Vienna, 2015, ISBN 78-3-903063-44-0, 434 p.

Terziev, Venelin. (2015a). Assessment of active social policies impact of social policies on transformation processes in bulgarian economy, Moscow, 2015, Publisher „Перо“, 110 p.

Terziev, Venelin. (2015b). Opportunities for improving the efficiency of the social adaptation of servicemen discharged from military service in Bulgaria:- Novosibirsk: Publisher CRNS, 2015. ISBN 978-5-00068- 
402-3, $270 \mathrm{p}$.

Terziev, V., E., Arabska. (2016a). Effektivnoe vliyanie na raynok truda posredstvom uluchsheniya realizatsii sotsialynoy politiki. Novosibirsk: Izdatelystvo TSRNS, 2016. ISBN 978-5-00068-496-2, 312 str (Терзиев, В., Е. Арабска. (2016а). Эфрфективное влияние на рынок труда посредством улучшения реализации социальной политики. Новосибирск: Издательство ЦРНС, 2016. ISBN 978-5-00068-496-2, 312 стр). 